\title{
The contribution of the Barn owl (Tyto alba) feeding ecology to confirm bat species occurrence in north Portugal
}

\author{
Hélia Marisa Vale-Gonçalves ${ }^{1}$, Paulo Barros ${ }^{1}$, Luís Braz $^{1} \&$ João AleXandre Cabral ${ }^{1}$ \\ ${ }^{1}$ Laboratory of Applied Ecology \\ Centre for the Research and Technology of Agro-Environment and Biological Sciences (CITAB) \\ University of Trás-os-Montes and Alto Douro (UTAD), Vila Real (Portugal). \\ *Corresponding author e-mail: helia@utad.pt
}

DOI: http://dx.doi.org/10.14709/BarbJ.8.1.2015.05 (C) 2015 Published by SECEMU.

Spanish title: Contribución de la ecología alimentaria de la lechuza común (Tyto alba) para confirmar la presencia de especies de quirópteros en el norte de Portugal

\begin{abstract}
The Barn owl (Tyto alba) is an opportunistic species which feeds mainly on small mammals but also on birds, bats, reptiles, amphibians, insects and fishes. With regard to bats, several studies in Europe suggest that this group constitutes a small portion of the Barn owl diet representing less than $1 \%$ of its prey items. Through the analysis of 2,934 Barn owl pellets, collected between 2006 and 2014 in 27 sites/nests located in north Portugal, the remains of six bats belonging to five species were identified in a total of 9,103 prey items identified: the Western barbastelle (Barbastella barbastellus), the Grey long-eared bat (Plecotus austriacus), the Brown long-eared bat (Plecotus auritus), the European free-tailed bat (Tadarida teniotis) and the Common pipistrelle (Pipistrellus pipistrellus). These findings are of great interest as they represent new data on the Brown longeared bat and European free-tailed bat distributions, and allow to confirm an historical record of the Western barbastelle in the region.
\end{abstract}

Keywords: Bats distribution, Feeding ecology, Portugal, Pellets, Tyto alba.

The Barn owl (Tyto alba), a cosmopolitan nocturnal bird, is an opportunistic species which feeds mainly on small mammals (Taylor 1994, Meek et al. 2012). However, depending on prey's availability, birds, bats, reptiles, amphibians, insects and fishes represent alternative preys (Mikkola 1983, Taylor 1994, Sommer et al. 2005, Roulin \& Dubey 2012, 2013, Roulin \& Christe 2013, Roulin, 2015). Since the information from Barn owl pellets provides consistent information on the proportion and availability of prey through the species feeding territories (Taylor 1994), the analysis of the respective prey items is an extremely valuable indirect method to document their diversity, geographical distribution and population ecology (Colvin \& McLean 1986, Love et al. 2000, Torre et al. 2004, Avenant 2005).

Although some species of mammals, birds (including raptors), reptiles, amphibians and fishes are potential predators of bats, only few of them are specialized on this prey group (Gillette \& Kimbrough 1970, Sparks et al. 2000). Nevertheless, some studies reported that bats might represent between $27 \%$ and $51 \%$ of the prey items in the diet of some specialized raptors (Vargas et al. 2002, Sommer et al. 2009), particularly in favourable contexts, such as in the case of Tawny owl (Strix aluco) (Obuch 1998) and the Common kestrel (Falco tinnunculus) (Negro et al. 1992). These are, for instance, contexts where these raptors hunt bats as main prey in habitats associated with urban areas, mostly captured when emerging from roosts at dusk (Lesiński et al. 2009, Lima \& Keefe 2013). Conversely, the studies based on the feeding ecology of Barn owl in Europe suggest an opportunistic behaviour where bats constitute, on average, less than $1 \%$ of the prey items (Mikkola 1983, Obuch 1998, Avenant 2005, Sommer et al. 2005, Roulin \& Christe 2013, Bekker et al. 2014).

This study documents several bat species from Barn owl pellets collected in the north region of Portugal. The main goal is to update the knowledge about the distribution/occurrence of some of these species in this region. Potential Barn owl nest and roost sites were searched in the north-eastern districts of Vila Real, Bragança, Viseu and Guarda, in order to detect indirect evidences of the species occupation and to 
Table 1. Dental formulas and main distinctive characteristics of each bat genus identified in the Barn owl pellets collected from north of Portugal (Palmeirim, 1985; Paz \& Benzal, 1990; Jenrich et al., 2012).

\begin{tabular}{lll}
\hline Genus & $\begin{array}{l}\text { Dental formulas } \\
\left(\mathbf{I}^{\mathbf{n}} \cdot \mathbf{C}^{\mathbf{n}} \cdot \mathbf{P} \mathbf{M}^{\mathbf{n}} \cdot \mathbf{M}^{\mathbf{n}} / \mathbf{I}_{\mathbf{n}} \cdot \mathbf{C}_{\mathbf{n}} \cdot \mathbf{P} \mathbf{M}_{\mathbf{n}} \cdot \mathbf{M}_{\mathbf{n}}\right)\end{array}$ & Main distinctive characteristics \\
\hline Barbastella & $2.1 .2 .3 / 3.1 .2 .3$ & $\begin{array}{l}\text { Depressed short rostrum. Upper } \mathrm{C}^{1} \text { with } \\
\text { elongate section and flat inner surface with a } \\
\text { sharply defined cingulum. }\end{array}$ \\
\hline Plecotus & $2.1 .2 .3 / 3.1 .3 .3$ & $\begin{array}{l}\text { Maximal diameter of tympanic bulla twice as } \\
\text { large as the distance between them. }\end{array}$ \\
\hline Tadarida & $1.1 .2 .3 / 3.1 .2 .3$ & $\begin{array}{l}\text { Single pair of upper incisors. The skull is } \\
\text { depressed and its dorsal profile straight and } \\
\text { almost horizontal. }\end{array}$ \\
\hline
\end{tabular}

Pipistrellus 2.1.2.3/3.1.2.3 Gap between $\mathrm{PM}^{2}$ and $\mathrm{C}^{1}$. Nyctalodont molars.

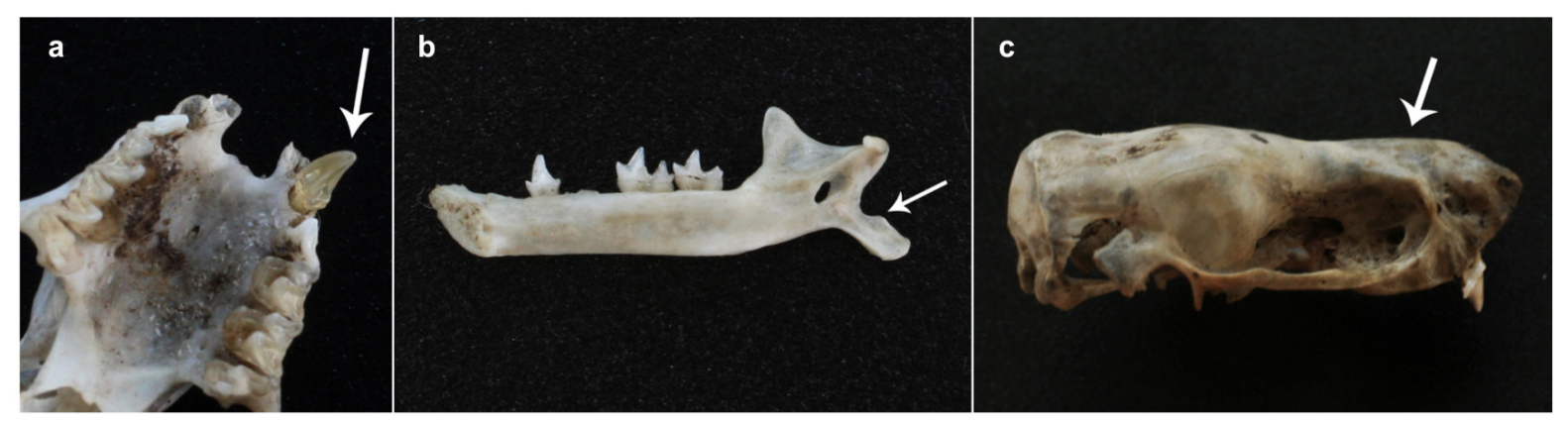

Fig. 1 - Bat skull remains identified in Barn owl pellets collected from north of Portugal: a - Upper canine of the Western barbastelle (Barbastella barbastellus) with elongate section and flat inner surface with a sharply defined cingulum; b - lower mandible of the Grey long-eared bat (Plecotus austriacus) with a salience on the processus angularis in the posterior part; $\mathrm{c}$ - a depressed and the dorsal profile of the European free-tailed bat (Tadarida teniotis) is straight and almost horizontal. The arrows indicate the respective distinctive morphological details.

confirm their potential as sampling points (Vale-Gonçalves \& Cabral 2014). Bat species were assessed by the analysis of Barn owl pellets collected between 2006 and 2014, following the methodological protocol described in Vale-Gonçalves \& Cabral (2014). Genera were identified through the dental formula and some other general distinctive characteristics (Table 1) (Palmeirim 1985, Paz \& Benzal 1990), whereas the species confirmation was carried out as described in Jenrich et al. (2012), particularly to Plecotus and Pipistrellus.

Among a total of 9,103 prey items identified, from the analysis of 2,934 Barn owl pellets collected in 27 sites/nests, six belong to five bat species $(n=6 ; 0.07 \%)$ : the Western barbastelle (Barbastella barbastellus, $\mathrm{n}=1 ; 0.01 \%$; Fig. 1a), the Grey long-eared bat (Plecotus austriacus, $\mathrm{n}=2 ; 0.02 \%$; Fig. 1b), the Brown long-eared bat (Plecotus auritus, $\mathrm{n}=1$; $0.01 \%$ ), the European free-tailed bat (Tadarida teniotis, $\mathrm{n}=1$; $0.01 \%$; Fig. 1c) and the Common pipistrelle (Pipistrellus pipistrellus, $\mathrm{n}=1 ; 0.01 \%$ ). Species of the genus Plecotus were distinguished by the differences in the shape of the processus angularis in the posterior part of the mandibles (Fig. 1b) (Jenrich et al. 2012). Regarding the species of the genus Pipistrellus, the identification was determined by comparisons of the size between the $\mathrm{I}^{1}$ and $\mathrm{I}^{2}$, and the shape of the processus angularis of the mandible (Table 1) (Jenrich et al. 2012).

When projected on a $10 \times 10 \mathrm{~km}$ UTM grid (datum WGS84), the localization of the pellets with bat remains allowed us to trace unknown occurrence areas for two species, namely the Brown long-eared bat and the European free-tailed bat, as well to confirm an historical record of the Western barbastelle (Fig. 2) (Rainho et al. 2013). The spatial localization of the pellets with these bat remains was displayed in a GIS environment (ArcMap 10.0®).

The Western barbastelle is a forest-dwelling bat, the occurrence of which is strongly associated to the presence of old-grow deciduous forests (Russo et al. 2010; Barros \& Braz 2013). In Portugal this species exhibits a fragmented distribution with higher abundances in the north and centre of the country (Rainho et al. 2013). With regard to the foraging habitat selection, this species is quite flexible, hunting in a range of habitats, including clearings, riverbanks, meadows and forests. 


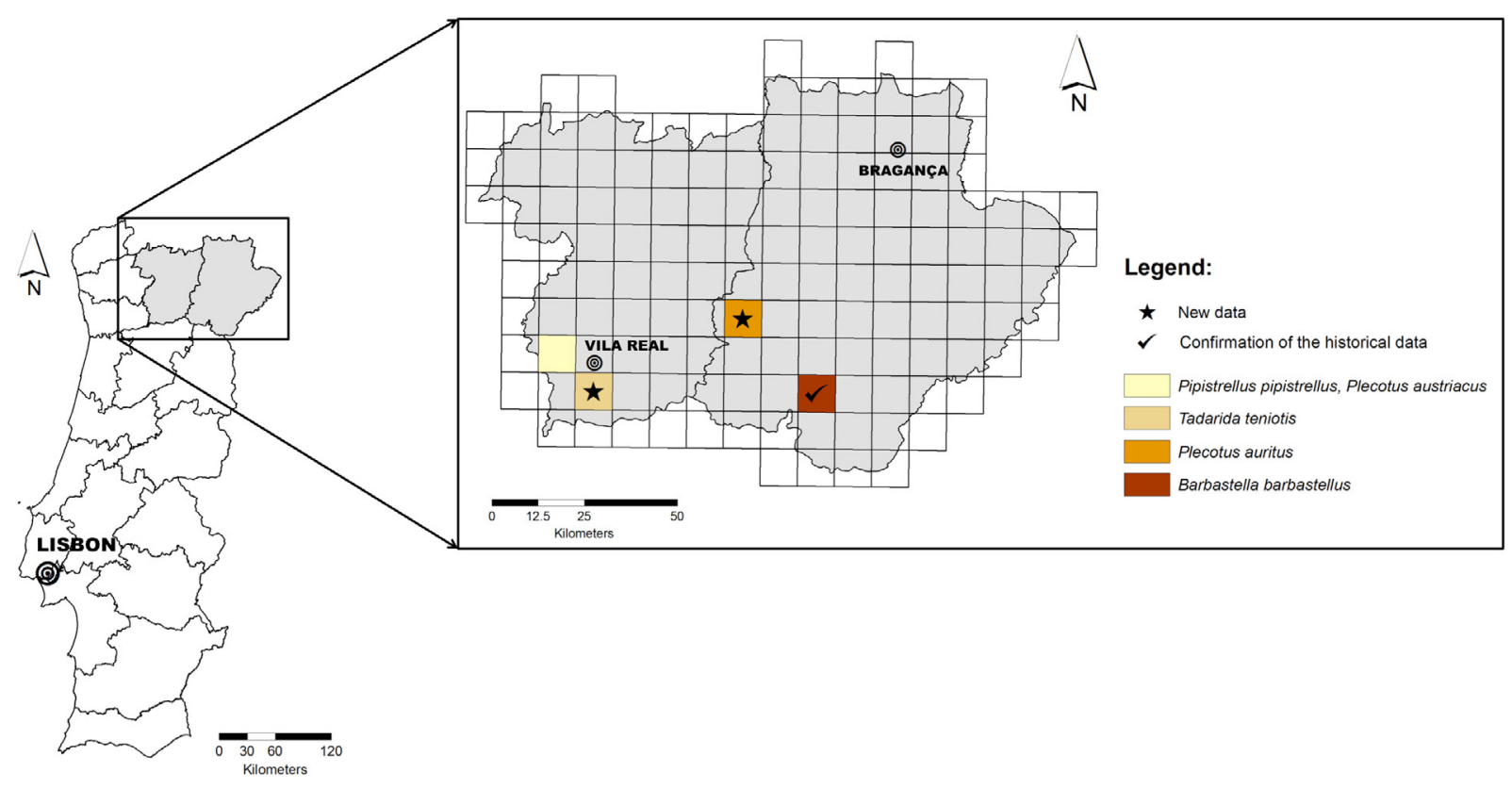

Fig. 2 - Localization of the bat species identified in the Barn owl pellets from north Portugal in a 10x10km UTM grid cells (Datum WGS84).

The Grey long-eared bat is primarily an open or edge habitat forager relatively common and well distributed throughout Portugal (Rainho et al. 2013). Its roosts are often located at the edge of villages, surrounded by open grasslands, well developed hedgerows and woodland patches. During summer this species seems to prefer available shelters in manmade roosts, mainly in the roof space of buildings, churches and barns, and in winter it can hibernate in underground galleries, mines and caves.

There are few records of the Brown long-eared bat in Portugal, which appears to be more abundant in the north, with a very fragmented distribution (Rainho et al. 2013). As an arboreal species, associated with the presence of forested areas, its roosts are usually cavities or cracks in trees, but also buildings (attics and caves, on churches and abandoned houses), usually located close to the feeding areas. During hibernation this species can be found in underground roosts (caves and mines). It is clearly a species more generalist than the congener Grey long-eared bat.

The European free-tailed bat is a medium-large crevicedweller, with a wide distribution in most of the mainland territory, although more abundant in the north (Rainho et al. 2013). It feeds in a wide variety of habitats, mostly above forests and olive grove areas, but it can also hunt over water bodies, urban and cultivated areas, with a home range from the roosts vicinity to more than $30 \mathrm{~km}$ away, between 10 and 300 meters above the ground.

The Common pipistrelle is a crevice-dweller bat actually considered the most generalist of the bat species with a widespread distribution and higher abundances in Portugal (Rainho et al. 2013). It can forage in a variety of habitats, such as agricultural areas, deciduous and evergreen forests, coniferous forests, urban and peri-urban areas and riparian galleries.
Three of these five bat species usually occur in artificial roosts, such as human houses. The Brown long-eared bat and the Western barbastelle are almost exclusively associated with woodlands, although they can also roost sporadically in bridges and buildings (Ruprecht 1979, Uhrin et al. 2010, Rainho et al. 2013).

Although the Barn owls are not specialized on hunting bats (Petrželková et al. 2004), several explanations have been proposed to clarify this unusual prey selection, suggesting a certain opportunism, namely when bats arrive at their hibernation sites and are caught during the exploratory flights (Sommer et al. 2009), or at the roosts' entrance during the periods of emergence and return (Petrželková et al. 2004, Lesiński et al. 2012, Lima \& Keefe 2013), or when both predator and prey shared a common roost (Lesiński et al. 2012).

Our results confirm that bats are not a preferential prey of the Barn owl in northern Portugal. However, although the number of items found in Barn owl pellets is residual, the data collected for bats may represent very important contributions, particularly for rare species, such as Western barbastelle, or species classified with the conservationist status of "data deficiency", as in the case of Western barbastelle, Brown long-eared bat and European free-tailed bat (Cabral et al. 2005). This is of particular relevance, since even in the most recent Atlas of bats in Portugal (Rainho et al. 2013) the data on the distribution of some species remain very scarce and incomplete, especially for species like the Western barbastelle, which is confirmed only in about $10 \%$ of the total of $1,00810 \times 10 \mathrm{~km}$ grid cells. Additionally, for bat species that are difficult or impossible to distinguish by acoustic methods, such as Brown long-eared bat, less than $2 \%$ of the referred grids were confirmed. Therefore, the new records for the Western barbastelle, the Brown long-eared bat and the European free-tailed bat represent an important update of the respective distribution data in the study area. 


\section{ACKNOWLedgments}

This study was supported by funding from several ecological monitoring projects of the Laboratory of Applied Ecology (University of Trás-os-Montes and Alto Douro, UTAD), including the grant BGCT/LEA/402/UTAD/2014 (Hélia Marisa Vale-Gonçalves), and by Portuguese Foundation for Science and Technology (FCT) through the project PEst-OE/AGR/UI4033/2014. A special thank is addressed to Sara Ramos and Octávia Veloso for helping in the analysis of some barn owl pellets.

\section{REFERENCES}

Avenant, N. L. 2005. Barn owls pellets: a useful tool for monitoring small mammal communities? Belgian journal of zoology, 135: 39-43.

Barros, P. \& Braz, L. 2013 Barbastella barbastellus (schreber, 1774) in mine from North Portugal, a case of "swarming"? barbastella, 6: 13-22. Doi: http:// dx.doi.org/10.14709/BarbJ.5.1.2012.01

Bekker, D., Janssen, R. \& Buys J. 2014. First records of predation of grey-long-eared bats (Plecotus austriacus) by the barn owl (Tyto alba) in the Netherlands. Lutra, 57: 43-47.

Cabral, M.,Almeida, J.,Almeida, P., Delinger, T., Ferrand Almeida, N., Oliveira, M., Palmeirim, J., Queiroz,A., Rogado, L. \& Santos-Reis M. 2005. Livro vermelho de vertebrados de Portugal. Instituto da Conservação da Natureza, Lisboa, Portugal.

Colvin, B. A. \& Mclean, E. B. 1986. Food habits and prey specificity of the Common Barn owl in Ohio. The Ohio Journal of Science, 86: 76-80.

Gillette, D. D. \& Kimbrough, J. D. 1970. Chiropteran mortality. In About Bats (eds B. H. Slaughter and D. W. Walton), pp. 262-281. Dallas Southern Methodist University Press, Dallas.

Jenrich, J., LöHR, P. W., Müller F. \& Vierhaus, H. 2012. Fledermäuse: Bildbestimmungsschlüssel anhand von Schädelmerkmalen. Imhof Verlag.

LESIŃSKI G., KASPRZYK K. \& GRYZ J. 2012. Bats taken by the Tawny owl in relation to its roosting site. NorthWestern Journal of Zoology, 8: 247-251.

Lesiński, G., GrYZ, J. \& Kowalski, M. 2009. Bat predation by tawny owls Strix aluco in differently human-transformed habitats. Italian Journal of Zoology, 76: 415-421. Doi: http://dx.doi. org/10.1080/11250000802589535

Lima, L. S \& KeEFE, J. M. 2013. Do predators influence the behaviour of bats? Biological Reviews, 88: 626-644. Doi: http://dx.doi.org/10.1111/brv.12021
Love, R. A., Webbon C., Glue D. E. \& Harris S. 2000. Changes in the food of British Barn owls (Tyto alba) between 1974 and 1997. Mammal Review, 30: 107129.

Meek, W. R., Burman P. J., Sparks T. H., Nowakowski M. \& Burman N. J. 2012. The use of Barn Owl Tyto alba pellets to assess population change in small mammals. Bird Study, 59: 166-174. Doi: http://dx.doi. org/10.1046/j.1365-2907.2000.00060.x

Mikкola, H. 1983. Owls of Europe (eds.), Calton.

Negro, J. J., Ibánez C., Pérezjordá J. L. \& Delarivo M. J. 1992. Winter predation by Common kestrel Falco tinnunculus on pipistrelle bats Pipistrellus pipistrellus in Southern Spain. Bird Study, 39: 195-199. Doi: http://dx.doi.org/10.1080/00063659209477118

OBuch, J., 1998. The representation of bats (Chiroptera) in the diet of the owls (Strigiformes) in Slovakia. Vespertilio, 3: 65-75.

PaLmeirim, J.M. 1985. Bats from Portugal: Zoogeography and systematics. Tese de Mestrado, University of Kansas. 53pp. Doi: http://dx.doi.org/10.5962/bhl. title. 4060

Paz, O. \& Benzal, J. 1990. Clave para la identificación de los murciélagos de la Península Ibérica. Miscelánea Zoológica, 13: 153-176.

PetržElková, K. J., Obuch J. \& Zuka. J. 2004. Does the barn owl (Tyto alba) selectively predate individual great mouse-eared bats (Myotis myotis)? Lynx, 35: 123-132.

Rainho, A., Alves P., Amorim F. Et Al. 2013. Atlas dos morcegos de Portugal Continental. Instituto da Conservação da Natureza e das Florestas. 76pp.

Roulin, A. \& Christe P. 2013. Geographic and temporal variation in the consumption of bats by European Barn Owls. Bird Study, 60: 561-569. Doi: http:// dx.doi.org/10.1080/00063657.2013.847051

Roulin, A. \& Dubey S. 2012. The occurrence of reptiles in Barn Owl diet in Europe. Bird Study, 59: 504-508.

Roulin, A. \& Dubey S. 2013. Amphibians in the diet of European Barn Owls. Bird Study, 60: 264-269. Doi: http://dx.doi.org/10.1080/00063657.2013.767307

Roulin, A. 2015. Spatial variation in the decline of European birds as shown by the Barn owl Tyto alba diet. Bird Study, Doi: http://dx.doi.org/10.1080/00063657.2015 .1012043 .

Ruprecht, A. L. 1979. Bats (Chiroptera) as constituents of the food of barn owls Tyto alba in Poland. Ibis, 121: 489-494. Doi: http://dx.doi.org/10.1111/j.1474919X.1979.tb06690.x 
Russo, D., Cistrone, L., Garonna, A. P. \& Jones, G. 2010. Reconsidering the importance of harvested forests for the conservation of tree-dwelling bats. Biodiversity and Conservation, 19: 2501-2515. Doi: http://dx.doi. org/10.1007/s10531-010-9856-3

Sommer, R., Niederle, M., Labes, R. \& Zoller, H. 2009. Bat predation by the barn owl Tyto alba in a hibernation site of bats. Folia Zoologica, 58: 98-103.

Sommer, R., Zoller, H., Kock, D., Böhme, W. \& Griesau, A. 2005. Feeding of the barn owl, Tyto alba with first record of the European free-tailed bat, Tadarida teniotis on the island of Ibiza (Spain, Balearics). Folia Zoologica, 54: 364-370.

Sparks, D. W., Roberts, K. J. \& Jones, C. 2000. Vertebrate predators on bats in North America north of Mexico. In Reflections of a Naturalist: Papers Honoring Professor Eugene D. Fleharty, Fort Hays Studies Special Issue 1 (ed. J. R. Choate), pp. 229-241. Fort Hays State University, Hays, Kansas.
TAYLOR, I. 1994. Barn Owls: Predator-prey relationships and conservation (eds.). Cambridge.

Torre, I., Arrizabalaga A. \& Flaquer C. 2004. Three methods for assessing richness and composition of small mammal communities. Journal of Mammalogy, 85: $524-530$.

Uhrin, M., Benda, P., Obuch, J. \& Urban, M. 2010. Changes in abundance of hibernating bats in central Slovakia (1992-2009). Biologia, 65: 349-361. Doi: http://dx.doi.org/10.2478/s11756-010-0020-z

Vale-Gonçalves, H. M. \& Cabral J. A. 2014. New records on the distribution of three rodent species in NE Portugal from barn owl (Tyto alba) diet analysis. Galemys, 26: 100-104. Doi:_http://dx.doi.org/10.7325/ Galemys.2014.N3

Vargas, J., Landaeta C. \& Simonetti J. A. 2002: Bats as prey of Barn Owls (Tyto alba) in a tropical savanna in Bolivia. Journal of Raptor Research, 36: 146-148. 